\title{
EXPRESSION OF THE BCL2 GENE IN CHRONIC LYMPHOCYTIC LEUKAEMIA PATIENTS
}

\author{
Ksenija Vucicevic ${ }^{1}$, Vladimir Jakovljevic ${ }^{2}$, Jasmina Sretenovic ${ }^{2}$, Natasa Tosic ${ }^{3}$, Tatjana Kostic ${ }^{3}$, Irena Glumac ${ }^{3}$, Milica Colovic ${ }^{4}$, \\ Natasa Colovic ${ }^{4,5}$, Sonja Pavlovic ${ }^{3}$, Teodora Karan-Djurasevic ${ }^{3}$ \\ ${ }^{1}$ Department of Pharmacy, Faculty of Medical Sciences, University of Kragujevac, Kragujevac, Serbia \\ ${ }^{2}$ Department of Physiology, Faculty of Medical Sciences, University of Kragujevac, Kragujevac, Serbia \\ ${ }^{3}$ Institute of Molecular Genetics and Genetic Engineering, University of Belgrade, Belgrade, Serbia \\ ${ }^{4}$ Clinic for Haematology, Clinical Centre of Serbia, Belgrade, Serbia \\ ${ }^{5}$ Medical Faculty, University of Belgrade, Belgrade, Serbia
}

\section{EIKSPESIJA BCL2 GENA KOD PACIJENATA SA HRONIČNOM} LIMFOCITNOM LEUKEMIJOM

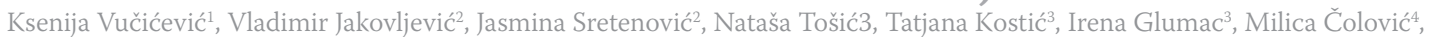
Nataša Čolović ${ }^{4,5}$, Sonja Pavlović ${ }^{3}$, Teodora Karan-Đuraševićc ${ }^{3}$

${ }^{1}$ Odsek za farmaciju, Fakultet medicinskih nauka, Univerzitet u Kragujevcu, Kragujevac, Srbija

${ }^{2}$ Katedra za fiziologiju, Fakultet medicinskih nauka, Univerzitet u Kragujevcu, Kragujevac, Srbija ${ }^{3}$ Institut za molekularnu genetiku i genetičko inženjerstvo, Univerzitet u Beogradu, Beograd, Srbija ${ }^{4}$ Klinika za hematologiju, Klinički centar Srbije, Beograd, Srbija

Received / Primljen: 25.12.2014 ${ }^{5}$ Medicinski fakultet, Univerzitet u Beogradu, Beograd, Srbija

Accepted / Prihvaćen: 20.02.2015

\begin{abstract}
Chronic lymphocytic leukaemia (CLL) manifests as clonal expansion of mature B lymphocytes, whose accumulation is primarily attributed to the dysregulation of apoptosis. Aberrant expression, as well as genetic alterations within various Bcl2 family members and central regulators of the intrinsic, mitochondriamediated apoptotic pathway all hasve been observed in CLL. Here, we report the expression analysis of the anti-apoptotic Bcl2 gene in a cohort of 58 CLL patients. Quantitative reverse-transcriptase polymerase chain reaction (qRT-PCR) analysis revealed a significant overexpression of $B c l 2 m R N A$ in $C L L$ samples compared to control samples $(p=<0.001)$. Receiver operating characteristic (ROC) analysis showed that the level of Bcl2 expression exerts a high discriminatory power between patients and healthy subjects ( $A=0.98,95 \% C I=0.95-1.009, p<0.0001)$.
\end{abstract}

Key-words: Chronic lymphocytic leukaemia, apoptosis, $B c l 2$, expression analysis

\section{SAŽETAK}

Hronična limfocitna leukemija (HLL) se manifestuje kao klonska ekspanzija zrelih B limfocita, cija se akumulacija pripisuje prvenstveno poremećajima procesa apoptoze. $U$ HLL su uočene genetičke promene i aberantna ekspresija različitih članova Bcl2 genske familije, koji imaju ključnu ulogu u regulaciji unutrašnjeg, mitohondrijskog puta aktivacije apoptoze. U ovom radu je analizirana ekspresija anti-apoptotskog Bcl2 gena u grupi od 58 pacijenata obolelih od HLL. Metodom kvantitativnog RT-PCRa detektovana je povišena ekspresija Bcl2 mRNA u HLL uzorcima u odnosu na kontrolne uzorke ( $p=<0.001)$. "Receiver operating characteristic" (ROC) analiza je pokazala da nivo ekspresije Bcl2 ima visoku moć diskriminacije između pacijenata $i$ zdravih kontrola ( $A=0.98,95 \%$ CI=0.95-1.009, $p<0.0001$ ).

Ključne reči: Hronična limfocitna leukemija, apoptoza, Bcl2, analiza ekspresije

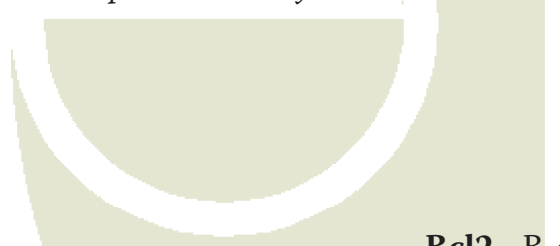

Bcl2 - B-cell lymphoma 2 CLL - Chronic lymphocytic leukaemia mRNA - messenger ribonucleic acid

\section{INTRODUCTION}

Chronic lymphocytic leukaemia (CLL) is the most frequent type of leukaemia in Western countries, affecting predominantly elderly individuals (aged 65 and over). It manifests as monoclonal expansion of small, mature CD5 ${ }^{+}$ $\mathrm{CD} 19^{+} \mathrm{CD}_{23}{ }^{+} \mathrm{sIgM}^{\text {low }} \mathrm{B}$ lymphocytes. CLL is characterized by extremely variable clinical presentations, from indolent to rapidly progressive, with different therapy requirements and overall survival $(1,2)$.
Circulating CLL B lymphocytes are arrested in $\mathrm{G}_{0}$ /early $G_{1}$ phase of the cell cycle (3), and their gradual accumulation in blood, bone marrow and secondary lymphoid organs is primarily a result of impaired apoptosis.

The Bcl 2 family is a group of evolutionary conserved proand anti-apoptotic proteins coded by $B c l 2$ family genes, which are involved in the regulation of the intrinsic, mitochondriamediated pathway of apoptosis. All $\mathrm{Bcl} 2$ family proteins con- 
tain at least one of four highly conserved $\alpha$-helical BH (Bcl2 homology) domains (BH1, BH2, BH3 and BH4). Anti-apoptotic members $\left(\mathrm{Bcl} 2, \mathrm{Bcl}-\mathrm{X}_{\mathrm{L}}, \mathrm{Mcl}-1, \mathrm{~A} 1, \mathrm{Bcl}-\mathrm{W}\right)$ contain all four $\mathrm{BH}$ domains and a $\mathrm{C}$-terminal transmembrane domain. The pro-apoptotic members are divided into "multidomains" (Bax, Bak, Bok), containing BH1-3 and a transmembrane domain, and "BH3-only" (Bim, Bad, Bid, Bik, Bmf, Hrk, Noxa, Puma), containing only the $\mathrm{BH} 3$ domain (4). In the absence of apoptotic stimulus, pro-apoptotic members reside in the cytosol, whereas anti-apoptotic are anchored to the mitochondrial membrane and suppress the release of cytochrome c, which is crucial for activation of the caspase cascade and execution of apoptosis (5). Upon receiving a death stimulus, pro-apoptotic proteins translocate from the cytosol to the mitochondrial membrane and interact with anti-apoptotic proteins, ultimately leading to cytochrome c release (6).

$\mathrm{BH}$ domains are sites of interaction between $\mathrm{Bcl} 2 \mathrm{fam}$ ily members; this interaction is essential for homo- and heterodimerization, which is one of the main mechanisms of their action. In addition to o prototypical $\mathrm{Bcl} 2 / \mathrm{Bax}$ dimer formation, other interactions among $\mathrm{Bcl} 2$ family proteins can occur. In addition to dimerization, their activity is modulated through regulation at both transcriptional and post-translational levels (7).

Genetic and epigenetic alterations, as well as aberrant expression of various $B c l 2$ family genes, have been observed in CLL (8).

Leukaemic B lymphocytes from the majority of CLL patients (>80\%) express high levels of $B c l 2$, a typical antiapoptotic member of the $B c l 2$ family (9). The expression is higher not only in comparison to normal B lymphocytes but also when compared to cells that harbour translocation $t(14 ; 18)$, which places the $B c l 2$ gene in close proximity to the immunoglobulin heavy chain enhancer (10). Translocation $\mathrm{t}(14 ; 18)$ is common in follicular lymphoma but is a very rare event in CLL. It has been demonstrated that in a high proportion of patients, the $B c l 2$ promoter is hypomethylated, leading to increased transcription (11). In addition, overexpression of $\mathrm{Bcl} 2$ has been linked to downregulation or loss of miR-15a and miR-16-1. These miRNAs negatively regulate $\mathrm{Bcl} 2$ at the post-transcriptional level and are located within the deletion of $13 \mathrm{q} 14$, the most frequent genomic aberration in CLL $(12,13)$. Furthermore, Bcl2 overexpression has been reported to associate with $-938 \mathrm{C}>\mathrm{A}$ promoter polymorphism (14); however, this finding was not confirmed by subsequent research (15). The prognostic significance and therapeutic implications of the $\mathrm{Bcl} 2$ gene and protein expression level are still under investigation due to conflicting results obtained in different studies.

The aim of this study was to analyse the expression of the $B c l 2$ gene in patients with chronic lymphocytic leukaemia.

\section{PATIENTS AND METHODS}

This study enrolled 58 unselected patients from the Clinic for Haematology, Clinical Centre of Serbia (Belgrade,
Serbia), who were diagnosed with typical B cell CLL based on clinical criteria and laboratory features. The study was approved by the medical ethics committee of the institution.

The patient group consisted of 45 men and 13 women $($ male/female ratio $=3.5)$, with a median age of 63.5 years (range: 39 - 86) at the time of diagnosis.

The distribution of clinical Binet stages was as follows: 22 patients (42.3\%) stage A, 7 patients (13.5\%) stage B and 23 patients $(44.2 \%)$ stage $C$ (the staging information was unavailable for 6 patients).

The control group consisted of 10 healthy individuals, 3 men and 7 women, with a median age of 53 years (range: $44-84)$.

Peripheral blood mononuclear cells (PBMCs) of all patients contained $>90 \%$ of CLL lymphocytes, as confirmed by immunophenotyping. PBMCs were isolated by Ficoll density-gradient centrifugation, and total RNA was extracted using TRI reagent (Sigma-Aldrich). The isolated RNA was reverse-transcribed using RevertAid M-MuLV Reverse Transcriptase (Fermentas) and random hexamer primers according to the manufacturer's instructions.

$\mathrm{Bcl} 2$ mRNA expression was analysed by quantitative reverse-transcriptase polymerase chain reaction (qRT-PCR) using SYBR Green chemistry in a 7500 Real Time PCR system (Applied Biosystems). The specific primers used for qRT-PCR amplification were 5'-TCGCCCTGTGGATGACTGA-3' (forward) and 5'CAGAGACAGCCAGGAGAAATC-3' (reverse). The amplification of Abl using the following primers: forward 5'-TGGAGATAACACTCTAAGCATAACTAAAGGT-3' and reverse 5'-GATGTAGTTGCTTGGGACCCA-3', served as an internal control. The reaction mixture contained $50 \mathrm{ng}$ cDNA, 1 x Power SYBR ${ }^{\circ}$ Green PCR Master Mix (Applied Biosystems) and $0.5 \mathrm{pmol}(\mathrm{Bcl} 2)$ or $2 \mathrm{pmol}(\mathrm{Abl})$ of each gene-specific primer with a final reaction volume of $10 \mu \mathrm{l}$. The cycling conditions were as follows: denaturation of the template at $95^{\circ} \mathrm{C}$ for 10 minutes, followed by 40 cycles of $95^{\circ} \mathrm{C}$ for 15 seconds and $60^{\circ} \mathrm{C}$ for 1 minute. Each qRT-PCR reaction was performed in duplicate in order to evaluate reproducibility of the results. Quantification of target gene expression was performed using the comparative ddCt method with the HL-60 cell line as the calibrator.

Statistical analyses were performed using the MannWhitney rank-sum test, Spearman rank order correlation and receiver operating characteristic (ROC) analysis. All statistical tests were carried out using Sigma Stat 3.5 and SigmaPlot 11.0 software (Systat Software Inc.). Statistical significance was defined as $\mathrm{p}<0.05$.

\section{RESULTS}

In this study, we analysed the expression of the $B c l 2$ gene in a cohort of 58 unselected patients with chronic lymphocytic leukaemia.

Using qRT-PCR methodology for expression analysis, we detected significantly higher levels of $B c l 2$ mRNA in CLL samples compared to non-leukaemic samples ( $\mathrm{p}=<0.001)$ (Fig. 1). 


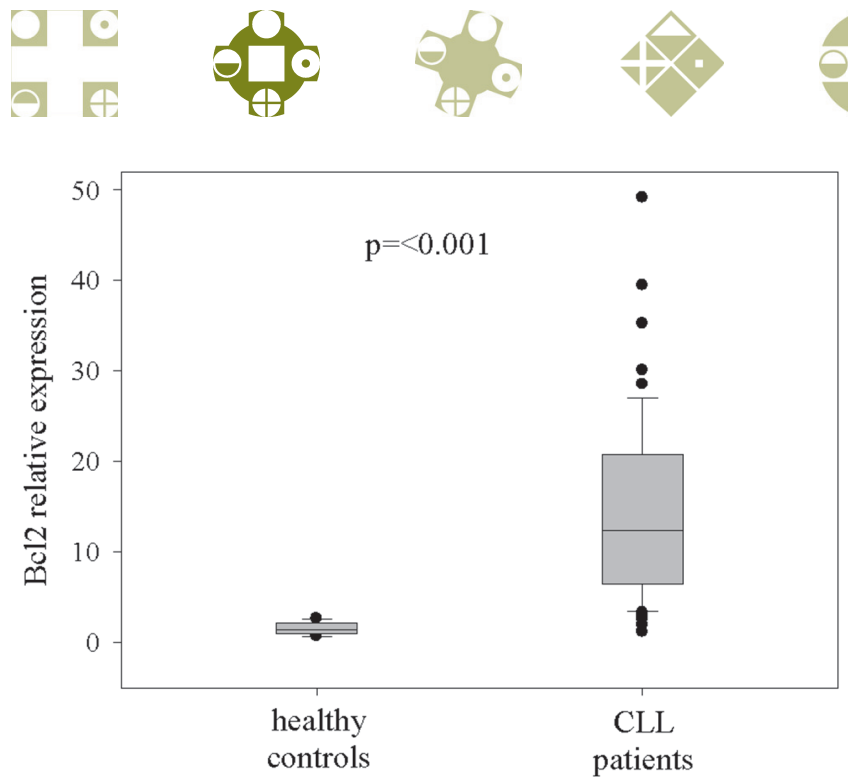

Figure 1

Relative expression of $B c l 2$ mRNA in CLL and non-leukaemic samples qRT-PCR analysis showed a significantly higher expression of $B c l 2$ in mononuclear cells of CLL patients in comparison to healthy controls $(\mathrm{p}=<0.001$; Mann-Whitney Rank Sum Test).

In addition, we observed a wide variability in the expression of $B c l 2$ among CLL patients (1.168-49.146 relative units), in contrast to relatively homogeneous expression among healthy controls (0.685-2.629 relative units). We performed receiver operating characteristic (ROC) analysis in order to evaluate the discriminatory power of $\mathrm{Bcl} 2$ expression in CLL. ROC analysis demonstrated that $B c l 2$ mRNA expression efficiently distinguished CLL from control samples (cut-off $=\mathbf{2 . 7 6}$ relative units, $\mathrm{A}=0.98,95 \% \mathrm{CI}=0.95-1.009, \mathrm{p}<0.0001$ ), exerting an excellent positive predictive value $(\mathrm{PPV}=1)$ and a slightly lower negative predictive value (NPV=0.77) (Fig. 2).

$B c l 2$ expression level did not show any association with either gender or Binet staging. However, a significant negative correlation with the age of patients at diagnosis $(r=-$ $0.4, \mathrm{p}=0.004$ ) was detected.

\section{DISCUSSION}

Dysregulation of apoptosis is considered to be a hallmark of chronic lymphocytic leukaemia. In addition to the pro-survival influence of the microenvironment-derived signals, intrinsic defects of different apoptotic pathways have been identified in CLL cells, rendering them resistant to apoptosis. For example, the function of the ATM-p53 pathway is often abrogated by $11 \mathrm{q} 22-\mathrm{q} 23$ and $17 \mathrm{p} 13$ deletions, which exert the most adverse prognostic impact among all genomic aberrations detected in CLL. Deletions, as well as mutations and aberrant expression of p53 and ATM, have been associated with progressive disease and shorter overall survival $(16,17,18)$. Impaired function of other apoptotic pathways, namely the PI3K/Akt pathway $(19,20,21)$, NF-kB pathway $(19,22)$ and Fas/FasL system $(23,24)$, have also been implicated in CLL.

The role of the $\mathrm{Bcl} 2$ family of proteins has been extensively studied in CLL because they are key regulators of

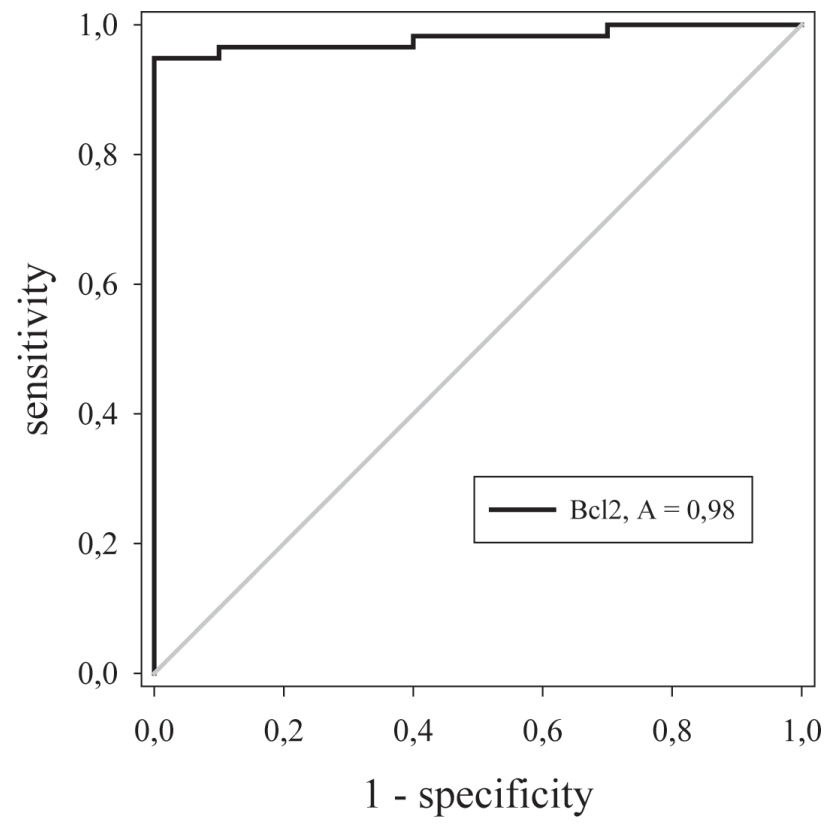

Figure 2

ROC analysis of $B c l 2$ expression in CLL and non-leukaemic samples $B c l 2$ mRNA expression exerts high discriminatory power between CLL patients and healthy controls.

$(\mathrm{A}=0.98$, sensitivity $=0.95$, specificity $=1,95 \% \mathrm{CI}=0.95-1.009, \mathrm{p}<0.0001)$ Abbreviations: ROC, receiver operating characteristic; A, area under the ROC curve; CI, confidence interval.

the mitochondrial apoptotic pathway. Genetic alterations and aberrant expression of various pro- and anti-apoptotic members have been observed in different studies. In addition to $\mathrm{Bcl} 2$, elevated expression in CLL patients vs. healthy controls of other $\mathrm{Bcl} 2$ family proteins and genes has been observed, namely Mcl1, BclX $\mathrm{L}_{\mathrm{L}}$ and Bcl2L12 (25,26,27). Moreover, in several studies, an upregulation of pro-apoptotic members was observed as well (28), which may seem paradoxical given the longevity of CLL cells. However, this is thought to represent a mechanism by which cells try to compensate for an excess of anti-apoptotic proteins through elevation of their functional antagonists. It should be noted though, that in other studies, pro-apoptotic Bax, Bak and BclX were observed to be underexpressed (29). Moreover, it is generally accepted that relative expression and/or activity levels, rather than the levels of individual proteins, are critical determinants of CLL cells' susceptibility to apoptosis.

Overall, the results of different studies regarding the relationship between the expression of $\mathrm{Bcl} 2$ family proteins and genes and the clinical behaviour of CLL are highly discrepant, and no consistent correlation with the disease stage, clinical progression or response to treatment could be established.

In this study, we analysed the expression of $B c l 2$ and anti-apoptotic members of the $B c l 2$ family in CLL patients and healthy controls.

In concordance with other reports, we observed a significant overexpression of $B c l 2$ in CLL samples compared to 
non-leukaemic samples. According to the calculated cut-off level, $94.8 \%$ of patients in our cohort were high-expressing $B c l 2$ cases. Although we detected a substantially wide range of $\mathrm{Bcl} 2 \mathrm{mRNA}$ expression levels among patients, they overlapped to a very small degree with those of healthy controls; therefore, the ROC analysis showed that the $B c l 2$ expression level efficiently discriminates CLL from normal samples.

In our study, no association between $B c l 2$ mRNA expression and clinical stage of CLL was detected. However, the results of other studies regarding the association of $\mathrm{Bcl} 2$ protein expression with clinical stage remain controversial. In several cohorts, $\mathrm{Bcl} 2$ expression was higher in advanced stages of the disease $(30,31)$, while in others, such a correlation could not be demonstrated $(28,32)$. The lack of association with clinical stage reopens the question of whether elevated $\mathrm{Bcl} 2$ expression is acquired during leukemogenesis, or if elevated $\mathrm{Bcl} 2$ expression beganwas present in the originating cells of CLL (33). It should be noted that both staging systems currently in use, Rai and Binet, were applied in these studies, which may have led to the inconsistency of the results.

In summary, the findings of the present study further support the hypothesis that $B c l 2$ overexpression plays a role in the pathogenesis of CLL. To what extent inter-patient variability in $B c l 2$ expression contributes to the clinical heterogeneity of CLL has yet to be elucidated.

Research on the mRNA expression levels of anti-apoptotic $\mathrm{Bcl}-2$ family members in human cancer cell lines using qRT-PCR techniques and the assessment of the ability of known Bcl-2 inhibitors to induce cell death within them revealed that the effectiveness of known $\mathrm{Bcl}-2$ inhibitors depends on the mRNA expression profile of tumor cells. The correlation between the cell-killing properties of known Bcl-2 inhibitors and the relative mRNA expression levels of anti-apoptotic $\mathrm{Bcl}-2$ family members has been observed in leukaemia cell lines and has provided critical insights into apoptosis-based anticancer strategies that target $\mathrm{Bcl}-2$ proteins (34). Moreover, gene expression profiling emphasizes the value of the follow up of molecular markers in CLL patients (especially mRNA expression of $B c l 2$ and NOXA) in order to facilitate the choice of an effective treatment for individual patients (35). Therefore, the Bcl2 mRNA expression profile of each patient could lead to personalized treatment. Thus, the methodology used in this study represents a promising tool for individualization and optimization of therapy for CLL patients.

\section{ACKNOWLEDGEMENT}

This work was supported by grant No. III 41004, Ministry of Education and Science, Republic of Serbia.

\section{CONFLICT OF INTEREST}

The authors declare that they have no conflict of interest.

\section{REFERENCES}

1. Sagatys EM, Zhang L. Clinical and laboratory prognostic indicators in chronic lymphocytic leukemia. Cancer Control 2012;19(1):18-25.

2. Chiorazzi N. Implications of new prognostic markers in chronic lymphocytic leukemia. Hematology Am Soc Hematol Educ Program 2012;2012:76-87.

3. Obermann EC, Went P, Tzankov A, et al. Cell cycle phase distribution analysis in chronic lymphocytic leukaemia: a significant number of cells reside in early G1phase. J Clin Pathol 2007;60(7):794-7.

4. Thomadaki H, Scorilas A. BCL2 family of apoptosisrelated genes: functions and clinical implications in cancer. Crit Rev Clin Lab Sci 2006;43(1):1-67.

5. Garrido C, Galluzzi L, Brunet M, et al. Mechanisms of cytochrome c release from mitochondria. Cell Death Differ 2006;13(9):1423-33.

6. Leibowitz B, Yu J. Mitochondrial signaling in cell death via the Bcl-2 family. Cancer Biol Ther 2010;9(6):417-22.

7. Burlacu A. Regulation of apoptosis by Bcl-2 family proteins. J Cell Mol Med 2003;7(3):249-57.

8. Tzifi F, Economopoulou C, Gourgiotis D, et al. The Role of BCL2 Family of Apoptosis Regulator Proteins in Acute and Chronic Leukemias. Adv Hematol 2012;2012:524308.

9. Mariano MT, Moretti L, Donelli A, et al. bcl-2 gene expression in hematopoietic cell differentiation. Blood 1992;80(3):768-75.

10. Meijerink JP. $t(14 ; 18)$, a journey to eternity. Leukemia 1997;11(12):2175-87.

11. Hanada M, Delia D, Aiello A, Stadtmauer E, Reed JC. bcl-2 gene hypomethylation and high-level expression in B-cell chronic lymphocytic leukemia. Blood 1993;82(6):1820-8.

12. Calin GA, Dumitru CD, Shimizu M, et al. Frequent deletions and down-regulation of micro- RNA genes miR15 and miR16 at 13q14 in chronic lymphocytic leukemia. Proc Natl Acad Sci U S A 2002;99(24):15524-9.

13. Cimmino A, Calin GA, Fabbri M, et al. miR-15 and miR-16 induce apoptosis by targeting BCL2. Proc Natl Acad Sci U S A 2005;102(39):13944-9.

14. Nuckel H, Frey UH, Bau M, et al. Association of a novel regulatory polymorphism $(-938 \mathrm{C}>\mathrm{A})$ in the BCL2 gene promoter with disease progression and survival in chronic lymphocytic leukemia. Blood 2007;109(1):290-7.

15. Majid A, Tsoulakis O, Walewska R, et al. BCL2 expression in chronic lymphocytic leukemia: lack of association with the BCL2 938A>C promoter single nucleotide polymorphism. Blood 2008;111(2):874-7.

16. Dohner H, Stilgenbauer S, Benner A, et al. Genomic aberrations and survival in chronic lymphocytic leukemia. N Engl J Med 2000;343(26):1910-6.

17. Pettitt AR, Sherrington PD, Stewart G, et al. p53 dysfunction in B-cell chronic lymphocytic leukemia: inactivation of ATM as an alternative to TP53 mutation. Blood 2001;98(3):814-22. 
18. Rossi D, Cerri M, Deambrogi C, et al. The prognostic value of TP53 mutations in chronic lymphocytic leukemia is independent of Del17p13: implications for overall survival and chemorefractoriness. Clin Cancer Res 2009;15(3):995-1004.

19. Cuni S, Perez-Aciego P, Perez-Chacon G, et al. A sustained activation of $\mathrm{PI} 3 \mathrm{~K} / \mathrm{NF}-\mathrm{kappaB}$ pathway is critical for the survival of chronic lymphocytic leukemia $B$ cells. Leukemia 2004;18(8):1391-400.

20. Ringshausen I, Schneller F, Bogner C, et al. Constitutively activated phosphatidylinositol-3 kinase (PI-3K) is involved in the defect of apoptosis in BCLL: association with protein kinase Cdelta. Blood 2002;100(10):3741-8.

21. Barragan M, Bellosillo B, Campas C, et al. Involvement of protein kinase $\mathrm{C}$ and phosphatidylinositol 3-kinase pathways in the survival of B-cell chronic lymphocytic leukemia cells. Blood 2002;99(8):2969-76.

22. Hewamana S, Alghazal S, Lin TT, et al. The NF-kappaB subunit Rel A is associated with in vitro survival and clinical disease progression in chronic lymphocytic leukemia and represents a promising therapeutic target. Blood 2008;111(9):4681-9.

23. Panayiotidis P, Ganeshaguru K, Foroni L, Hoffbrand AV. Expression and function of the FAS antigen in $B$ chronic lymphocytic leukemia and hairy cell leukemia. Leukemia 1995;9(7):1227-32.

24. Osorio LM, Aguilar-Santelises M, De Santiago A, et al. Increased serum levels of soluble Fas in progressive BCLL. Eur J Haematol 2001;66(5):342-6.

25. Pepper C, Lin TT, Pratt G, et al. Mcl-1 expression has in vitro and in vivo significance in chronic lymphocytic leukemia and is associated with other poor prognostic markers. Blood 2008;112(9):3807-17.

26. Vogler M, Butterworth M, Majid A, et al. Concurrent up-regulation of BCL-XL and BCL2A1 induces approx- imately 1000-fold resistance to ABT-737 in chronic lymphocytic leukemia. Blood 2009;113(18):4403-13.

27. Karan-Djurasevic T, Palibrk V, Zukic B, et al. Expression of Bcl2L12 in chronic lymphocytic leukemia patients: association with clinical and molecular prognostic markers. Med Oncol 2013;30(1):405.

28. Robertson LE, Plunkett W, McConnell K, Keating MJ, McDonnell TJ. Bcl-2 expression in chronic lymphocytic leukemia and its correlation with the induction of apoptosis and clinical outcome. Leukemia 1996;10(3):456-9.

29. Caligaris-Cappio F, Hamblin TJ. B-cell chronic lymphocytic leukemia: a bird of a different feather. Journal of Clinical Oncology 1999;17:399-408.

30. Faderl S, Keating MJ, Do KA, et al. Expression profile of 11 proteins and their prognostic significance in patients with chronic lymphocytic leukemia (CLL). Leukemia 2002;16(6):1045-52.

31. Aviram A, Rabizadeh E, Zimra Y, et al. Expression of bcl-2 and bax in cells isolated from B-chronic lymphocytic leukemia patients at different stages of the disease. Eur J Haematol 2000;64(2):80-4.

32. Saxena A, Viswanathan S, Moshynska O, et al. Mcl-1 and $\mathrm{Bcl}-2 / \mathrm{Bax}$ ratio are associated with treatment response but not with Rai stage in B-cell chronic lymphocytic leukemia. Am J Hematol 2004;75(1):22-33.

33. Packham G, Stevenson FK. Bodyguards and assassins: Bcl-2 family proteins and apoptosis control in chronic lymphocytic leukaemia. Immunology 2005;114(4):441-9.

34. Placzek WJ, Wei J, Kitada S, et al. A survey of the antiapoptotic Bcl-2 subfamily expression in cancer types provides a platform to predict the efficacy of $\mathrm{Bcl}-2$ antagonists in cancer therapy. Cell Death Dis 2010;1:e40.

35. Rogalinska M, Franiak-Pietryga I, Blonski JZ, et al. Toward personalized therapy for chronic lymphocytic leukemia: DSC and cDNA microarray assessment of two cases. Cancer Biol Ther 2013;14(1):6-12. 